\title{
ANALISIS STRATEGI PROMOSI E-COMMERCE SHOPEE YANG MEMPENGARUHI KEPUTUSAN PEMBELIAN KONSUMEN
}

\author{
${ }^{1}$ Fellya Salsabilla Nadiansyah, ${ }^{2}$ Rully Indrawan, ${ }^{3}$ Saiful Almujab \\ 1,2,3 Pendidikan Ekonomi FKIP Universitas Pasundan \\ Alamat e-mail : ${ }^{1}$ fellyasabill26@gmail.com, ${ }^{2}$ rully.Indrawan@unpas.ac.id, \\ 3. saifulalmujab@unpas.ac.id
}

\begin{abstract}
The purposes of this research are to find out the intensity of the use of shopee ecommerce, the promotional strategies carried out by the e-commerce shopee and the promotion strategies of the shopee e-commerce which most significantly influence the purchasing decisions of students of the Pasundan University Economics Education Study Program. The research method used is a survey method with a quantitative approach, with a sample of 202 students of the Economic Education Study Program, FKIP Pasundan University. Techniques in collecting data using questionnaires and data analysis techniques using multiple linear regression analysis. The results showed that the intensity of the use of e-commerce shopee among students of the economic education study program was at a high level as indicated by the number of respondents as many as 202 shopee e-commerce users who felt regular promos from shopee so that they could answer every statement of each promotional strategy variable that owned by e-commerce shopee, the promotional strategies carried out by e-commerce shopee to influence purchasing decisions consist of five, namely, free shipping promos, promo floods, games with prizes, various payment methods, and shopee express services and partially promotional strategies in the form of promo floods the most significant influence on purchasing decisions with a coefficient of determination $\left(R^{2}\right)$ of $49.7 \%$.

Keywords: Promotion Strategy, E-commerce, Shopee, Purchase Decision
\end{abstract}

\section{ABSTRAK}

Penelitian ini bertujuan untuk mengetahui intensitas penggunaan e-commerce shopee, strategi promosi yang dilakukan oleh e-commerce shopee dan strategi promosi e-commerce shopee yang paling signifikan mempengaruhi keputusan pembelian mahasiswa Program Studi Pendidikan Ekonomi Universitas Pasundan. Metode penelitian yang digunakan adalah metode survey dengan pendekatan kuantitatif, dengan sampel berjumlah 202 mahasiswa Program Studi Pendidikan Ekonomi FKIP Universitas Pasundan. Teknik dalam pengumpulan data menggunakan angket dan teknik analisis data menggunakan analisis regresi linier berganda. Hasil penelitian menunjukkan bahwa intensitas penggunaan e-commerce shopee pada mahasiswa program studi pendidikan ekonomi dalam taraf yang tinggi ditunjukkan dengan jumlah responden sebanyak 202 orang pengguna e-commerce shopee yang merasakan promo rutin dari shopee sehingga dapat menjawab setiap pernyataan-pernyataan setiap variabel strategi promosi yang dimiliki e-commerce shopee, strategi promosi yang dilakukan e-commerce shopee untuk mempengaruhi keputusan pembelian terdiri dari lima yaitu, promo gratis ongkir, banjir promo, permainan berhadiah, beragam metode pembayaran, dan layanan shopee express dan secara parsial strategi promosi berupa banjir promo yang paling signifikan mempengaruhi keputusan pembelian dengan nilai koefisien determinasi $\left(R^{2}\right)$ sebesar $49,7 \%$.

Kata kunci : Strategi Promosi, E-commerce, Shopee, Keputusan Pembelian 


\section{PENDAHULUAN}

Dalam era Revolusi Industri 4.0 masyarakat secara tidak sadar, sudah dipaksa dalam membiasakan diri untuk hidup dalam teknologi yang baru. Salah satu kemajuan teknologi informasi yang sangat pesat yaitu internet. Saat ini besarnya jumlah pengguna internet membuat segala aktivitas dapat dilakukan secara online. Tidak terkecuali dengan berbelanja, sejak adanya internet jual beli online menjadi tren baru di masyarakat. Kegiatan jual beli melalui elektronik dimana pembeli, penjual, pemasaran produk dan transaksi penjualan dengan menggunakan jaringan internet dilakukan secara digital atau dengan istilah lain dikenal dengan e-commerce.

Menurut Hartman et al. (2000) dalam buku "Net Ready-Strategies for Success in the E-Economy" mengemukakan bahwa e-commerce merupakan mekanisme bisnis yang menitikberatkan pada transaksi bisnis individu, menggunakan internet sebagai media pertukaran barang atau jasa baik antara dua buah institusi B-to-B maupun antar institusi dan konsumen langsung B-to-C.

Kemudahan melakukan pemesanan dan pembayaran secara digital yang ditawarkan oleh e-commerce menjadi pilihan untuk memenuhi kebutuhan dan keinginan secara online. Terutama pada saat ini, akibat mewabahnya Covid-19 terjadi perubahan perilaku dimana konsumen lebih memilih untuk melakukan segala kegiatan yang berbasis contactless. Membuat industri e-commerce di Indonesia terlihat sangat prospektif saat ini. Berdasarkan laporan Global Web Index tahun 2020 dalam RCTI Ads (2020) Indonesia memiliki tingkat adopsi e-commerce tertinggi di dunia dimana 90\% pengguna internet dengan rentan usia dari 16-64 tahun di Indonesia pernah melakukan transaksi belanja online. Pesatnya perkembangan ekonomi berbasis elektronik mempunyai potensi ekonomi yang tinggi bagi Indonesia. Sehingga pertumbuhan e-commerce terus meningkat membuat berbagai e-commerce terus bermunculan. Dalam industri ini ada 10 e-commerce terpopuler di Indonesia yaitu Tokopedia, Shopee, Bukalapak, Lazada, Blibli, Jd Id, Orami, Bhinneka, Sociolla, dan Zalora. Berikut statistik pengguna e-commerce di Indonesia pada Kuartal IV 2020 :

Pengunjung Bulanan Situs E-Commerve (Kuartal III 2020)

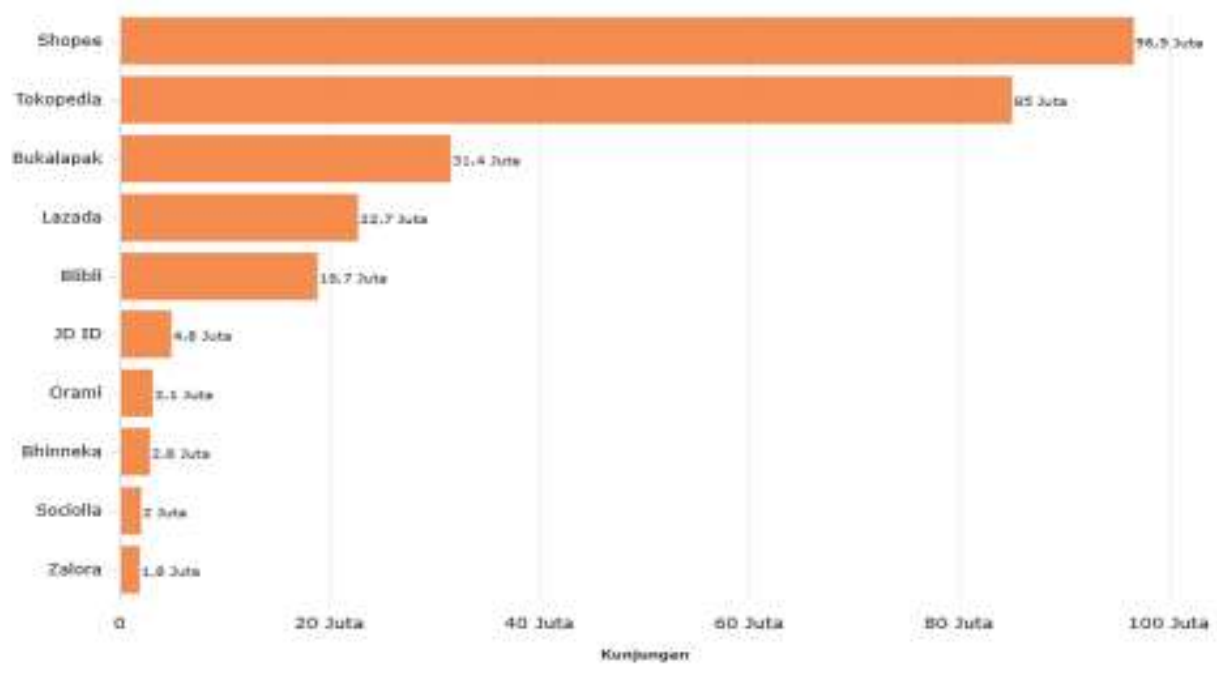

Sumber : (Jayani, 2020) 


\section{Gambar 1}

Statistik Pengguna E-commerce di Indonesia pada Kuartal IV 2020

Menjamurnya perusahaan-perusahaan e-commerce di Indonesia mambuat persaingan bisnis antara perusahaan e-commerce menjadi sangat ketat. Ketatnya persaingan tersebut membuat tidak semua perusahaan e-commerce dapat bertahan dan berhasil mendapatkan keuntungan dari usaha yang sudah dijalankan. Menurut hasil penelusuran yang dilakukan oleh Iprice (2020) menunjukkan perusahaan ecommerce yang tumbang, terdiri dari empat perusahaan yang berganti nama dan dua belas perusahaan yang tutup.

Dari data tersebut beberapa e-commerce seperti Qlapa, yaitu perusahaan yang mulai beroperasi tahun 2015 untuk menyediakan kerajinan tangan yang sempat mendapatkan investor bernama Aaviskhaar asal India dengan investasi Seri A, pada tahun 2019 tepatnya awal Maret mereka menghentikan operasionalnya secara menyeluruh. Pada 2 tahun sebelum Qlapa menutup kegiatan jual belinya, tepatnya tahun 2017 secara berurutan e-commerce Cipika yang merupakan layanan yang ditawarkan Indosat Ooredoo dengan produk kategori elektronik dan makanan serta LolaLola yang menyediakan produk pakaian dalam khusus perempuan yang didanai oleh Adent Ventures asal Thailand juga terpaksa berhenti beroperasi.

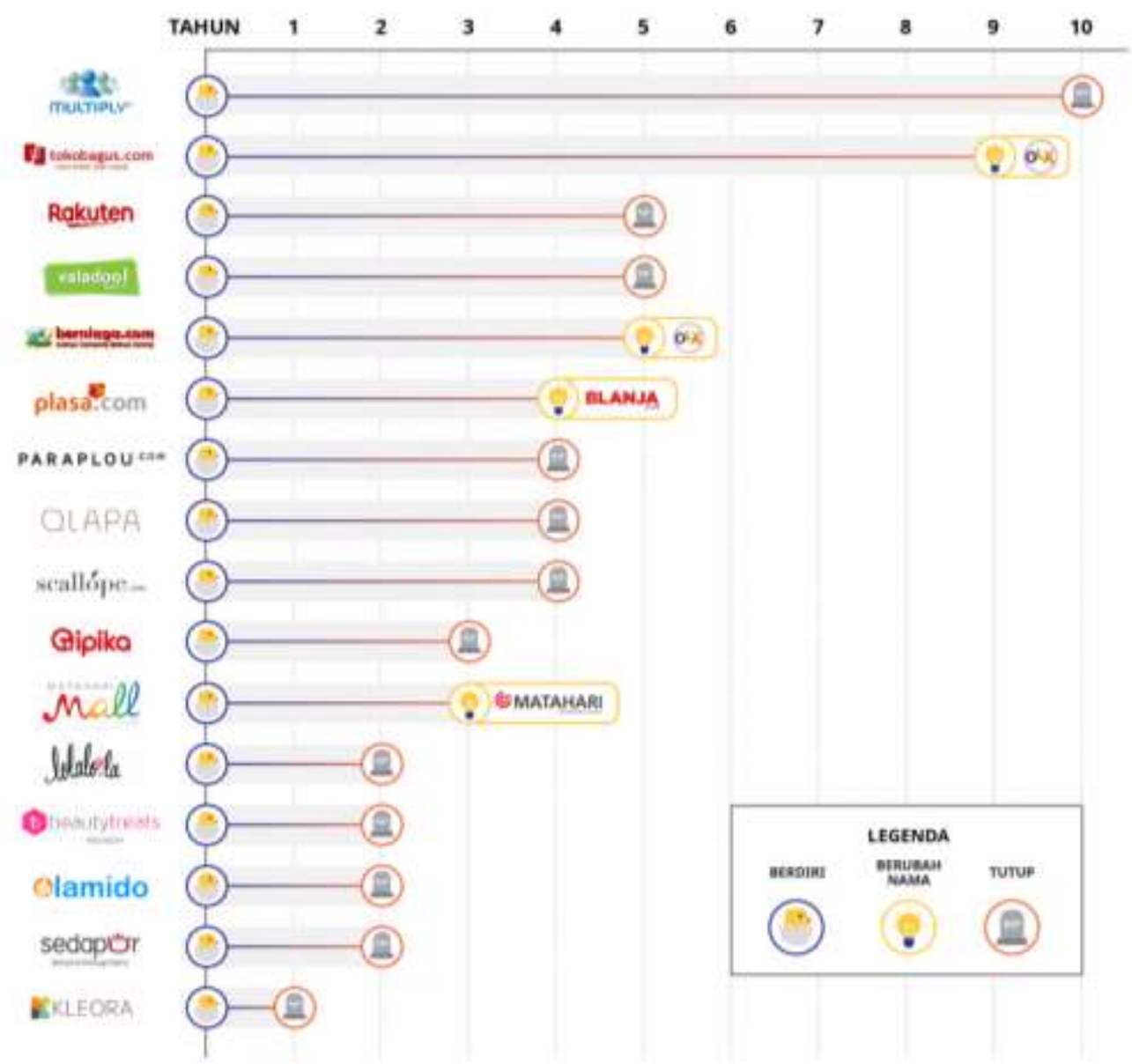

Sumber : (Iprice, 2020)

\section{Gambar 2}

Umur Perusahaan E-commerce yang Tumbang di Indonesia 
Dari banyaknya e-commerce yang tutup, ada catatan terkait penyebab hal tersebut dapat terjadi. Rata-rata penyebab e-commerce tersebut berhenti beroperasi karena strategi promosi yang kurang efektif sehingga permintaan atau minat dari konsumen dalam menggunakan e-commerce tersebut rendah. Hal tersebut terjadi karena saat ini perilaku konsumen berubah menjadi lebih kritis, lebih pintar, lebih sadar harga, dan lebih menuntut. Perilaku konsumen tersebut dapat mempengaruhi keputusan pembelian. Keputusan pembelian menurut Fandy (2014, hlm. 21) adalah suatu proses dimana konsumen menyadari masalah, mencari informasi tentang produk atau merek tertentu, dan mengevaluasi sejauh mana solusi alternatif dapat menyelesaikan masalah, dan dengan demikian memperoleh keputusan pembelian.

Sehingga setiap perusahaan e-commerce harus memahami beberapa tahap keputusan pembelian konsumen tersebut karena konsumen merupakan aset penting perusahaan. Shopee sebagai e-commerce menggunakan segala upaya atau strategi yang perusahaan lakukan untuk menarik hati konsumen. Salah satu strategi yang penting dilakukan untuk menarik pelanggan adalah strategi promosi.

Menurut Tjiptono \& Diana (2019, hlm. 469) strategi promosi penjualan adalah merencanakan kegiatan untuk meningkatkan permintaan konsumen guna meningkatkan pendapatan penjualan. Kegiatan tersebut dilakukan dengan mempengaruhi langsung keputusan pembelian konsumen. Strategi promosi yang dilakukan shopee yaitu menawarkan lima promo tetap untuk konsumen, yaitu promo gratis ongkir, banjir promo, permainan berhadiah, berbagai metode pembayaran, dan layanan shopee express. Semua Promo yang ditawarkan tersebut membuat berbelanja di shopee lebih aman, nyaman dan akan lebih mendorong konsumen untuk membuat keputusan pembelian.

Oleh karena itu peneliti merasa bahwa diperlukan penelitian untuk mengetahui intensitas penggunaan e-commerce shopee dan strategi promosi e-commerce yang secara signifikan mempengaruhi keputusan pembelian. Agar dapat memberikan manfaat bagi keilmuan tentang strategi promosi pada e-commerce yang mempengaruhi keputusan pembelian dan dapat dijadikan sebagai informasi cara pemanfaatan teknologi informasi masa kini dalam penerapan e-commerce untuk usaha bisnis dan dapat memberi keuntungan yang tinggi pada saat ini.

\section{LANDASAN TEORI}

\section{Strategi Promosi}

Strategi promosi adalah upaya suatu perusahaan dalam mengembangkan perusahaan agar dapat terus bertahan dalam jangka waktu yang panjang. Menurut Gitosudarmo (2014, hlm. 214-216), strategi promosi adalah sebuah kegiatan yang dirancang untuk mempengaruhi konsumen agar bisa mengetahui produk yang ditawarkan perusahaan, sehingga konsumen menjadi tertarik membeli produk tersebut. Strategi promosi terintegrasi mengacu pada upaya perusahaan untuk mengkoordinasikan elemen promosi untuk memaksimalkan persuasif pelanggan yang ada dan pelanggan potensial perusahaan. Dengan tujuan mencari keuntungan dan mendorong pembeli untuk melakukan keputusan pembelian. Swastha dan Irawan dalam Aflili et al. (2017) mengatakan "tujuan utama promosi adalah memodifikasi tingkah laku konsumen, menginformasikan, mempengaruhi, dan membujuk serta mengingatkan konsumen akan perusahaan serta produk atau jasa 
yang ditawarkan". Promosi tersebut dapat dinilai konsumen dengan indikator, Perhatian (Attention), Pemahaman (Readthrougness), Respon Kognitif (Cognitive), Respon Afektif (Affective), dan Sikap terhadap iklan (Behavior).

\section{E-commerce}

E-commerce dapat diartikan sebagai proses bisnis yang menggunakan teknologi elektronik, yang menghubungkan perusahaan, konsumen dan masyarakat dalam bentuk transaksi elektronik dan pertukaran atau penjualan barang, jasa dan informasi secara elektronik. Menurut Laudon \& Traver (2014, hlm 8-9) E-commerce didefinisikan sebagai transaksi komersial yang melibatkan pertukaran nilai melalui atau menggunakan teknologi digital antar individu. Untuk mengevaluasi suatu $e$ commerce terdapat beberapa variabel yang digunakan yang dikemukakan oleh Van Der Merwe \& Bekker (2003) yaitu, Interface (antara muka), Navigation (navigasi), Content (isi), Reliability (keandalan), dan Technical (teknis).

Dikutip dari laman Shopee (https://shopee.co.id) promo tetap yang menarik dan ditawarkan oleh Shopee untuk pelanggan, yaitu:

1.) Gratis Ongkir, pelanggan bisa dapat mendapatkan gratis ongkos kirim dimanapun daerah dan apapun belanjanya. Tak jarang kelebihan ini menjadi pertimbangan pelanggan untuk memutuskan pembelian.

2.) Banjir Promo, banyak promo yang ditawarkan selain gratis ongkos kirim antara lain ada diskon 90\%, cashback, dan flash sale.

3.) Permainan Berhadiah, inovasi dari Shopee untuk mengisi waktu luang pelanggan tetapi tetap mendapatkan hadiah.

4.) Beragam Pilihan Metode Pembayaran, kelebihan yang membuat pelanggan lebih mudah dan nyaman dengan menyediakan metode pembayaran yang variasi. Pembayaran dapat menggunakan Shopeepay, Shopee Pay Later, kartu kredit, transfer bank, indomaret, alfamart, oneklik, kredivo bahkan Cash On Delivery (COD).

5.) Layanan Shopee Express, salah satu kelebihan yaitu layanan pengiriman paket atau pesanan ditangani khusus oleh tim shopee, memiliki standar protokol kesehatan tinggi, mengandalkan layanan standar dan same day yang menjangkau berbagai daerah Indonesia.

\section{Keputusan Pembelian}

Keputusan pembelian adalah proses pengambilan keputusan yang diawali dengan pengenalan masalah dengan dihadapkan berbagai alternatif pilihan hingga memutuskan produk yang paling sesuai diantara banyaknya pilihan yang ada dan melakukan pembelian. Kotler \& Armstrong (2016) menjelaskan bahwa keputusan pembelian adalah bagian dari perilaku konsumen, perilaku konsumen yaitu studi tentang bagaimana individu, kelompok dan organisasi memilih, membeli, menggunakan, dan bagaimana barang, jasa ide atau pengalaman untuk memuaskan kebutuhan mereka.

Menurut Kotler dan Keller dalam Yulia et al. (2019, hlm. 114) menyebutkan bahwa terdapat lima tahap proses sebelum konsumen melakukan keputusan pembelian, yaitu sebagai berikut:

1.) Pengenalan Masalah

Proses konsumen dimulai dari mengenali masalah atau kebutuhan

2.) Pencarian Informasi 
Konsumen akan termotivasi untuk mencari lebih banyak informasi untuk mengetahui kebutuhannya.

3.) Evaluasi Alternatif

Konsumen memproses informasi dari berbagai merek atau e-commerce yang bersaing dan membuat penilaian akhir.

4.) Keputusan Pembelian

Setelah evaluasi, konsumen dapat membentuk niat dan membuat keputusan akhir untuk membeli merek dan memilih e-commerce tempat membeli kebutuhannya.

5.) Evaluasi Alternatif Setelah Pembelian

Setelah pembelian dan dikonsumsi, apabila konsumen senang dan puas akan barang dan e-commerce tempat melakukan transaksi pembelian ia akan memesan dan menggunakan kembali untuk memenuhi kebutuhannya.

Keputusan pembelian dapat diukur dengan enam indikator menurut Kotler \& Keller (2016, hlm. 479) yaitu :

1.) Pemilihan Produk (Product Choice)

Konsumen memutuskan produk mana yang akan dibeli, dan konsumen akan membeli produk yang berharga bagi mereka. Perusahaan harus tahu produk mana yang diinginkan oleh konsumen.

2.) Pemilihan Merek (Brand Choice)

Konsumen harus menentukan merek mana yang akan dibeli, dan setiap merek memiliki perbedaannya masing-masing. Dalam hal ini, perusahaan perlu memahami bagaimana konsumen memilih merek.

3.) Pemilihan Saluran Pembelian (Dealer Choice)

Konsumen harus memutuskan penyalur mana yang akan dikunjungi. Setiap konsumen berbeda dalam memilih penyalur, yang disebabkan oleh faktor-faktor seperti lokasi yang dekat, harga yang lebih murah, persediaan yang lengkap, belanja yang nyaman, dan lokasi yang fleksibel.

4.) Penentuan Waktu Pembelian (Purchase Timing)

Keputusan konsumen untuk membeli dengan penentuan waktu pembelian yang berbeda-beda.

5.) Jumlah Pembelian

Konsumen bisa menentukan berapa banyak produk yang akan dibeli sekaligus. Mungkin terdapat lebih dari satu produk yang dibeli, dalam hal ini perusahaan harus menyiapkan kuantitas produk sesuai dengan kebutuhan pembelian yang berbeda.

6.) Metode Pembayaran

Konsumen dapat mengambil keputusan tentang metode pembayaran yang akan dilakukan dalam pengambilan keputusan menggunakan konsumen menggunakan produk atau jasa.

\section{METODOLOGI}

Penelitian ini menggunakan metode survey, untuk mendapatkan data yang lebih akurat dari responden dalam penelitian ini adalah mahasiswa dalam memutuskan pembelian secara online. Dengan pendekatan kuantitatif dan analisis cross-sectional. 
Penelitian dilaksanakan di lingkungan Fakultas Keguruan dan IImu Pendidikan yang ditujukan kepada mahasiswa Program Studi Pendidikan Ekonomi. Dengan populasi dari penelitian ini adalah mahasiswa Program Studi Pendidikan Ekonomi Angkatan 2017, 2018, 2019, dan 2020, berjumlah 369 mahasiswa. Dari jumlah tersebut, sampel diambil dengan rumus Slovin dalam Umar (2013, hlm. 78) dengan tingkat kesalahan sebesar 5\%. Dari hasil perhitungan, didapatlah sejumlah 192 mahasiswa untuk dijadikan sampel. Alat pengumpulan data pada penelitian ini menggunakan kuesioner yang disebar kepada seluruh responden. Selanjutnya, dilakukan tabulasi data dan data diolah dengan menggunakan IBM SPSS 24.0 for windows untuk menganalisa uji asumsi klasik, uji hipotesis menggunakan uji $\mathrm{T}$ dan uji $\mathrm{F}$, dan uji koefisien determinasi.

\section{HASIL DAN PEMBAHASAN}

Untuk mengetahui strategi promosi e-commerce shopee yang mempengaruhi keputusan pembelian data pada penelitian ini diperoleh melalui penyebaran kuesioner, dimana variabel X1 5 pertanyaan, X2 5 pertanyaan, X3 5 pertanyaan, X4 5 pertanyaan, X5 5 pertanyaan, dan 6 pertanyaan untuk variabel Y. Berikut hasil analisis data setelah dilakukan penelitian:

1. Pengaruh Promo Gratis Ongkir terhadap Keputusan Pembelian

Berdasarkan analisis data dan melakukan uji hipotesis mengenai variabel promo gratis ongkir sebagai variabel satu pada penelitian ini, hasil Uji T parsial untuk Thitung variabel Promo Gratis Ongkir (X1) sebesar 4,419 dengan nilai signifikansi 0,00 serta Ttabel sebesar 1,972 . Hasil tersebut menunjukkan bahwa pada Uji T parsial nilai Thitung 4,419 > Ttabel 1,972, dan nilai pada perhitungan koefisien determinasi sebesar $44,2 \%$ yang menunjukkan variabel Promo Gratis Ongkir (X1) berpengaruh terhadap keputusan pembelian sebesar $44,2 \%$, artinya $\mathrm{HO}$ ditolak dan $\mathrm{H}$ a diterima untuk hipotesis 1.

2. Pengaruh Banjir Promo terhadap Keputusan Pembelian

Untuk variabel kedua yaitu Banjir promo berdasarkan hasil analisis data dan uji hipotesis menunjukkan pada Uji T parsial nilai Thitung 4,016 > Ttabel 1,972 nilai pada perhitungan koefisien determinasi sebesar $49,7 \%$ sehingga menunjukkan variabel Banjir Promo (X2) berpengaruh terhadap keputusan pembelian sebesar 49,7\%, artinya $\mathrm{HO}$ ditolak dan $\mathrm{Ha}$ diterima untuk hipotesis 2. Pada analisis deskriptif mayoritas responden setuju dengan adanya strategi promosi berupa banjir promo tersebut. Karena, melalui banjir promo tersebut harga produk cenderung miring dan masih termasuk banjir promo, yaitu flash sale yang berjalan 3 kali sehari dan menawarkan harga cuma-cuma.

3. Pengaruh Permainan Berhadiah terhadap Keputusan Pembelian

Variabel ketiga yaitu permainan berhadiah tujuannya strategi promosi ini agar konsumen dapat mengisi waktu luang tetapi tetap mendapatkan banyak hadiah dalam beragam bentuk, menunjukkan hasil analisis data dan uji hipotesis untuk nilai Thitung 1,539< Ttabel 1,972, nilai pada perhitungan koefisien determinasi hanya sebesar 20,2\% sehingga menunjukkan variabel Permainan Berhadiah (X3) berpengaruh terhadap keputusan pembelian sebesar $20,2 \%$, artinya $\mathrm{HO}$ diterima dan $\mathrm{Ha}$ ditolak untuk hipotesis 3. Artinya, Permainan berhadiah tidak signifikan mempengaruhi keputusan pembelian mahasiswa Program Studi Pendidikan Ekonomi 
Universitas Pasundan. Meskipun, hasil analisis data deskriptif menunjukkan mayoritas masih tertarik dengan strategi promosi berupa permainan berhadiah ini.

4. Pengaruh Beragam Metode Pembayaran terhadap Keputusan Pembelian

Berbeda dengan hasil analisis data dan uji hipotesis pada variabel keempat yaitu beragam metode pembayaran, pada Uji T menunjukkan nilai Thitung $3.087>$ Ttabel 1,972, nilai pada perhitungan koefisien determinasi sebesar $39,4 \%$ sehingga menunjukkan variabel Beragam Metode Pembayaran (X4) berpengaruh terhadap keputusan pembelian sebesar 39,4, artinya $\mathrm{HO}$ ditolak dan $\mathrm{H}$ a diterima untuk hipotesis 4 . Sesuai dengan hasil analisis data deskriptif responden mayoritas tertarik dengan strategi promosi menyediakan beragam metode pembayaran.

5. Pengaruh Layanan Shopee Express terhadap Keputusan Pembelian

Layanan shopee express, paket atau pesanan konsumen akan ditangani secara khusus membantu semua masalah dan kendala dalam pengiriman. Meskipun, hasil analisis data deskriptif menunjukkan mayoritas responden setuju dengan adanya strategi promosi berupa layanan shopee express namun pada uji hipotesis layanan shopee express nilai Thitung 1,967 < Ttabel 1,972, nilai pada perhitungan koefisien determinasi hanya sebesar $24,1 \%$ sehingga menunjukkan variabel Layanan Shopee Express (X5) berpengaruh terhadap keputusan pembelian sebesar $24,1 \%$, artinya $\mathrm{HO}$ diterima dan $\mathrm{H}$ a ditolak untuk hipotesis 5. Artinya, layanan shopee express tidak signifikan mempengaruhi keputusan pembelian mahasiswa Program Studi Pendidikan Ekonomi Universitas Pasundan.

6. Variabel yang Paling Signifikan Mempengaruhi Keputusan Pembelian

Berdasarkan hasil analisis data dan uji hipotesis Uji T, dapat disimpulkan strategi promosi e-commerce shopee yang mempengaruhi keputusan pembelian secara signifikan adalah strategi promosi berupa banjir promo mempengaruhi keputusan pembelian dengan nilai koefisien determinasi sebesar 49,7\%. Strategi promosi berupa promo gratis ongkir memiliki signifikansi kedua setelah promo gratis ongkir dengan nilai koefisien determinasi sebesar $44,2 \%$ dan signifikansi ketiga yaitu strategi promosi beragam metode pembayaran dengan nilai koefisien determinasi sebesar $39,4 \%$. Sedangkan untuk strategi promosi permainan berhadiah dan layanan shopee express secara signifikan tidak mempengaruhi keputusan pembelian dengan masingmasing nilai koefisien determinasi sebesar 20,2\% dan $24,1 \%$.

Hasil tersebut menunjukan bahwa strategi banjir promo memberikan kontribusi yang tinggi terhadap keputusan pembelian konsmen. Salah satu jenis strategi banjir promo di platform e-commerce shopee adalah 27 hari kampanye 10.10 Pada kampanye ini, Shopee menghadirkan berbagai pilihan brand terbaik untuk memenuhi berbagai kebutuhan pengguna yang sesuai dengan personifikasi masing-masing individu yang didukung 100 persen orisinalitas produk brand dalam Shopee Mall. Promo-promo yang dimaksud diantaranya Gratis Ongkir, Voucher Diskon 100RB, Flash Sale 100RB, Cashback Extra, Ingatkan Diskon, Big Brands Rush Hour, Voucher Brand Cashback 50 persen, TV Shopping, 10.10 Shopee Games Festival dan Super Brands Late Night Sale. Strategi seperti ini nampaknya bisa dijadikan rujukan oleh platform e-commerce lain Sebagian bagian dari strategi marketing perusahaan.

Secara simultan melalui Uji F menunjukkan nilai Fhitung 59,555 > Ftabel 2,259, sehingga menunjukkan variabel Promo Gratis Ongkir X1, Banjir Promo X2, Permainan Berhadiah X3, Beragam Metode Pembayaran X4, Layanan Shopee 
Express $X 5$ secara simultan berpengaruh terhadap variabel $Y$ yaitu Keputusan Pembelian. Serta output Koefisien Diterminasi diketahui bahwa nilai $R$ Square sebesar 0,604, artinya ada pengaruh dari variabel Promo Gratis Ongkir X1, Banjir Promo X2, Permainan Berhadiah X3, Beragam Metode Pembayaran X4, Layanan Shopee Express X5 secara simultan berpengaruh terhadap Keputusan Pembelian sebagai variabel $Y$ sebesar $60,4 \%$. Dari hasil tersebut penulis meyakini bahwa Strategi pemasaran dan promosi yang efektif mendorong kesuksesan jangka panjang, pengembangan pelanggan, dan profitabilitas bagi perusahaan. Dalam kaitannya dengan strategi promosi, peneliti meyakini setidaknya ada 3 hal yang perlu diperhatikan perusahaan terhadap strategi promosinya:

1) Bauran Pemasaran (Marketing Mix) Bauran pemasaran (Marketing Mix) merupakan alat utama yang digunakan dalam pengembangan bagian strategis dari rencana pemasaran perusahaan. Bauran pemasaran merupakan perpaduan dari empat elemen kunci yang digunakan untuk mengembangkan dan mempromosikan penawaran produ yaitu 1) komponen produk; 2) distribusi; 3) strategi penetapan harga; dan 3) promosi.

2) Penelitian dan Pengembangan

Salah satu tahap awal dari proses pemasaran adalah penelitian dan pengembangan produk dan layanan. Hal ini termasuk penggunaan berbagai studi penelitian kuantitatif dan kualitatif untuk mencari tahu apa yang pelanggan butuhkan atau inginkan. Pada akhirnya, untuk mempromosikan dan menjual produk dan mempertahankan pelanggan, perusahaan memerlukan solusi yang berkualitas dan diinginkan oleh pasar.

3) Strategi keberlanjutan

Proses pemasaran bersifat iteratif, artinya tidak pernah berakhir. Perusahaan dengan perspektif jangka panjang memahami bahwa setiap penelitian baru, pengembangan produk, dan kampanye promosi merupakan batu loncatan dalam pengembangan perusahaan yang sukses. Perusahaan dengan umur panjang terus-menerus meneliti, memantau tren yang berubah di pasar, membuat penyesuaian dari waktu ke waktu, dan menyegarkan kampanye promosi untuk mempertahankan citra merek mereka dan membuat orang tetap tertarik.

\section{SIMPULAN}

Berdasarkan penelitian, hasil pengolahan data, pengujian hipotesis, dan pembahasan dapat ditarik beberapa kesimpulan sebagai berikut :

1. Hasil penelitian strategi promosi e-commerce shopee yang berpengaruh secara parsial yaitu strategi promosi promo gratis ongkir, banjir promo, dan beragam metode pembayaran. Sedangkan stratagi promosi permainana berhadiah dan layanan shopee express tidak berpengaruh signifikan terhadap keputusan pembelian mahasiswa Program Studi Pendidikan Ekonomi Universitas Pasundan.

2. Hasil penelitian menunjukkan bahwa strategi promosi yang paling signifikan mempengaruhi keputusan pembelian adalah banjir promo dengan nilai koefisien determinasi sebesar 49,7\%. 
3. Promo Gratis Ongkir X1, Banjir Promo X2, Permainan Berhadiah X3, Beragam Metode Pembayaran X4, Layanan Shopee Express X5 secara simultan mempengaruhi keputusan pembelian. Setelah penelitian diadakan semakin menunjukkan bahwa strategi promosi dapat mempengaruhi dalam memilih penggunaan e-commerce dan keputusan pembelian.

\section{DAFTAR PUSTAKA}

Aflili, H., Kalangi, J., \& Walangitan, O. (2017). Pengaruh Promosi Terhadap Keputusan Menabung Nasabah. Jurnal Administrasi Bisnis, 5(006), 269393. https://doi.org/10.35797/jab.0.0.2017.18378.

Fandy, T. (2014). Pemasaran Jasa. Andi.

Gitosudarmo, I. (2014). Manajemen Pemasaran. BPFE.

Hartman, Amir, \& Sifonis, J. (2000). Net Ready: Strategies for Success in the. EConomy. McGraw-Hill Comp. Inc.

Iprice. (2020). Peta E-Commerce Indonesia. Iprice Insights. https://iprice.co.id/insights/mapofecommerce/

Jayani, D. H. (2020). Shopee, E-Commerce dengan Pengunjung Situs Tertinggi Kuartal III 2020.2 Databoks.Katadata.Co.Id. https://databoks.katadata.co.id/datapublish /2020/11/20/shopee-e-commercedengan-pengunjung-situs-tertinggi-kuartal-iii-2020

Kotler \& Keller. (2016). Capturing Marketing Insights (Electronic Version). In Marketing Management.

Kotler, P., \& Armstrong, G. (2016). Prinsip-Prinsip PEMASARAN Principle of Marketing. 1-63.

Laudon, K., \& Traver, C. G. (2014). E-Commerce 2014; 10th Edition. https://www.pearson.com/us/higher-education/product/Laudon-E-Commerce2014-10th-Edition/9780133024449.html

RCTI Ads. (2020). Membaca Peluang Industri E-commerce Indonesia di Tahun 2020. RCTI Ads. https://www.rctiads.com/blogs/membaca-peluang-industri-ecommerce-indonesia-di-tahun-2020

Tjiptono, F., \& Diana, A. (2019). Kepuasan Pelanggan. Andi Offset.

Umar, H. (2013). Metode Penelitian untuk Skripsi dan Tesis. Rajawali Press.

Van Der Merwe, R., \& Bekker, J. (2003). A framework and methodology for evaluating e-commerce Web sites. Internet Research, 13(5), 330-341. https://doi.org/ $10.1108 / 10662240310501612$

Yulia, farida, Lamsah, \& Periyadi. (2019). BUKU MANAJEMEN PEMASARAN_ compressed.pdf (Issue April, p. 79). 